\title{
Autism Susceptibility Genes Identification by Linkage Analysis: A Review
}

\author{
Vandana Rai \\ Department of Biotechnology, VBS Purvanchal University, Jaunpur 222001, \\ Uttar Pradesh, India \\ Telephone: 091-05452-252538(O), 091-05452-252320(R), 9453367088 (Mobile) \\ E-mail: raivandana11@rediffmail.com, raivandana@rediffmail.com
}

KEYWORDS Linkage. Genome-wide Screening. Candidate Gene. Neuro-development. Disorder

\begin{abstract}
Autism is a complex neuropsychiatry disorder that is heterogeneous both in its phenotypic expression and etiology. It is characterized by deficits in verbal communications, impairments in social interactions, and repetitive behaviors. Family studies have shown that autism runs in families and twin studies indicate that the basis of that familial aggregation is genetic. Numerous strategies are currently being employed to attempt to locate autism susceptibility genes-like linkage and candidate gene approaches, and during past decade several whole genome scan were carried out for the identification of autism susceptibility loci. These GWS and linkage studies have identified a number of suggestive loci most notably-2q, 7q, 15q11-13, 17q and Xq, but the results have been inconclusive and fine mapping and association studies have failed to identify the underlying genes. The purpose of this review is to evaluate the current status of autism susceptibility gene research.
\end{abstract}

\section{INTRODUCTION}

Autism is one of the most heritable complex genetic disorders in psychiatry and was first described in the early 1940s by Leo Kanner and Hans Asperger. Although a large proportion of individuals with autism manifest abnormal development from birth, a subset of at least 20$30 \%$ experience a regression with onset between 18 and 24 months of age after a period of apparently normal development. It is a lifelong neuro-developmental disorder characterized by three areas of abnormality: impairment in social interaction, impairment in communication, and restricted and repetitive patterns of interest or behavior (APA 1994; Rapin and Katzman 1998; Bailey et al.1996). The prevalence of this disability in the general population is over 1 in 1, 000 live births (Fombonne 2002), although a recent estimate indicate three times higher prevalence rate (Yeargin-Allsopp et al. 2003).

The etiology of this complex disease likely involves environmental factors, but it is highly heritable. Twin studies demonstrate concordance rates of $82-92 \%$ in monozygotic twins and 1$10 \%$ concordance rate in dizygotic twins. Sibling recurrence risk (6-8\%) is 35 times the population prevalence (Barrett et al. 1999; Muhle et al. 2004), making autism among the most heritable of all neuropsychiatric disorders.

A small percentage of individuals that are behaviorally autistic are affected by another disorder of known genetic cause - most commonly tuberous sclerosis (Baker et al.1998), fragile X syndrome (Rogers et al. 2001; Laumonnier et al. 2004), Down syndrome (Rasmussen et al. 2001), Sotos Syndrome ( Morrow et al.1990), Moebius syndrome (Gillberg and Steffenburg 1989), Williams syndrome (Reiss et al.1985), Phenylketonuria (Chen and Hsiao 1989; Miladi et al. 1992; Baieli et al. 2003), Duchenne muscular dystrophy (Komoto et al. 1984), Prader Willi syndrome (Descheemaeker et al. 2006), Angelmann syndrome (Steffenberg et al. 1996 ), Smith-Opitz-syndrome (Waage-Baudert et al. 2003) and Joubert syndrome (Ozonoff et al. 1999).

Research with modern neuro-imaging techniques such as magnetic resonance imaging (MRI), and positron emission tomography (PET) is beginning to map out the neural systems affected by autism. However, this work is still in its infancy. Recent progress has been made in identifying select brain systems that appear as part of the pathophysiology. Postmortem studies of a small number of persons with autism have revealed a range of abnormalities, including a significant decrease in the number of Purkinje cells and granule cells in the cerebellum (Bauman and Kemper 1994). The precise nature of these abnormalities, including a lack of gliosis indicative of scarring, suggests a prenatal origin. Of the specific brain regions implicated in the 
pathobiology of autism spectrum conditions, none has attracted as much interest as the limbic system, especially the amygdala and its functional partners in the temporal and frontal cortices. The amygdala, in particular, plays a critical role in emotional arousal, assigning significance to environmental stimuli, and mediating the formation of visual-reward associations or 'emotional' learning.

Scientists are using both indirect and direct approaches to identify autism susceptibility genes. Indirect approaches may also be helpful and include the characterization of less complex genetic disorders that share some of the symptoms such as RETT or Fragile X syndrome may result from disruption of gene or protein systems that may also be disrupted in cases of autism. Likewise, animal models may provide clues to genes and protein systems important in relevant behaviors, but it is unlikely that animal behaviors will fully parallel the human disorder. Postmortem and neuroimaging studies may inform genetic approaches (Veenstra-Vander Weele and Cook 2004). Direct approaches to identifying autism susceptibility genes include three overlapping methodologies: (i) chromosomal methods, including karyotyping and fluorescent in situ hybridization (FISH); (ii) linkage studies, including genome screens in affected sibling pairs; and (iii) gene association studies, including candidate gene studies. The ultimate goal of all of these techniques is to identify heritable genetic mutations in candidate genes that predispose an individual to autism or to traits associated with autism.

Research suggests that microscopic cytogenetic abnormalities may contribute to autism in approximately $7 \%$ of cases. Using various stains, the chromosomes of patients with autism are analyzed for visible breakpoints, translocations, duplications, and deletions. These regions are then scrutinized for the presence of genes that potentially are involved in the pathogenesis of autism (Yu et al. 2002; Reddy 2005; Christian et al. 2006; Marshall et al. 2008; Vorstman et al. 2006). All these investigations repeatedly report involvement of $2 \mathrm{q}, 7 \mathrm{q}$, and $15 \mathrm{q}$ regions in autism.

The candidate gene approach investigates a specific gene or genes for involvement in autism risk, genes are chosen for study based on either what is known about the gene's function, its location (for example in a recognized linkage peak), or a combination of both.
Over the past fifteen years, linkage analysis has been the primary approach to search for genes underlying complex diseases such as autism. Linkage is a powerful method to detect rare high-risk disease alleles. However, complex diseases are more likely to be caused by a combination of rare alleles and common variants that confer only a very modest disease risk, for which association analysis has more power. Family-based association studies compare the frequency of transmitted versus no transmitted parental alleles of polymorphic markers to affected individuals, whereas case-control association studies compare allele frequencies in affected individuals with unaffected controls to detect those that differ significantly between the two groups.

Genome-wide linkage analysis was viewed as a valuable approach for guiding the search for autism disease genes because this approach holds the advantage of scanning the genome for disease-associated loci in the absence of a priori hypotheses about the genetic architecture of a disease. There now exist more than a dozen genome-wide linkage studies of autism (Barrett et al. 1999; Philippe et al. 1999; Risch et al. 1999; Ashley-Koch et al. 1999; IMGSAC 1998 2001a; Buxbaum et al. 2004; Liu et al. 2001; Shao et al. 2002a; Auranen et al. 2002; Alarcon et al. 2005; Yonan et al. 2003; Ylisaukko-oja et al. 2004; Lamb et al. 2005; McCauley et al. 2005; Schellenberg et al. 2006; Trikalinos et al. 2006; Duvall 2007; Szatmari et al. 2007). Because most of these studies have applied different genotyping and analysis tools and include substantially overlapping samples, comparisons across them are complex. However, they have identified several common chromosomal regions as promising locations for autism vulnerability genes, including peaks on chromosomes $2 \mathrm{q}, 7 \mathrm{q}, 15 \mathrm{q}, 17 \mathrm{q}$ and $\mathrm{X}$ with the highest significance for region $7 \mathrm{q}$ (Barrett et al. 1999; IMGSAC, 2001a; Yonan et al. 2003).

\section{Chromosome 2q}

Buxbaum et al. (2001) and Shao et al. (2002b) identified linkage to chromosome $2 \mathrm{q}$, with sample of families with 'phrase speech delay' and indicated that genes involved with phrase speech delay phenotype may maps to this region. The IMGSAC also identified linkage to chromosome $2 \mathrm{q}$ in 152 affected sibling pairs (ASPs) in the 
follow-up to their first genome screen (IMGSAC 2001a). Several other linkage end genome-wide screen studies reported strong linkage to $2 \mathrm{q}$ region (IMGSAC 1998; Molloy et al. 2005). This region of interest harbors several genes likeNRXN1, SLC25A12, HOXD1, DLX1, DLX2, CENTG2, PAX3,

Neurexins encode a highly polymorphic family of neuronal proteins that interact with neuroligins to promote synaptic functioning. Neurexin gene (NRXN1) is located at the $2 \mathrm{q} 32$. Evidence for neurexin involvement in autism comes from a number of recent investigations (Szatmari et al. 2007; Kim et al. 2008; Yan et al. 2008). Feng et al. (2006) screened 3 neurexin beta genes in 72 individuals with autism and 535 controls, followed by sequencing of exon 1 of NRXN1 $\beta$ in additional 192 cases. They identified two heterozygous missense mutations (S14L and T40S) and a GG insertion in position 26 of the corresponding protein. People with autism carrying the S14L mutations apparently have seizures and facial dysmorphisms. Missense mutations were found in 4 individuals with autism and inframe deletions, and insertions were detected in 9 additional cases. In another study, a de novo heterozygous $300 \mathrm{~kb}$ deletion in the coding exons of the NRXN1 gene was found in two autistic sisters, one was non-verbal, whereas the other had mild language regression. In a recent casecontrol study by Yan et al. (2008), five rare patient-specific variants were identified in 116 autistic individuals whereas only one additional variant (G28A) was also found in controls. Finally, Kim et al. (2008) recently identified a number of rare coding variants in a scan of NRXN1 coding exons in 57 individuals with autism. The presence of deletions or other mutations also in unaffected siblings of patients with autism and even in controls (Kim et al. 2008; Yan et al. 2008) suggest that such mutations could confer vulnerability to autism rather than causing the disease.

The DLX1 (Distal-Less Homeobox 1) and DLX2 genes belong to the DLX family of homeobox transcription factors, which are essential for the development of forebrain GABAergic interneurons during embryonic development (Eisenstat et al. 1999). CENTG2 (Centaurin, Gamma-2) belongs to an ADP-ribosylation factor GTPase-activating (ARF-GAP) protein family involved in membrane traffic and actin cytoskeleton dynamics. CENTG2 expression occurs in whole brain and kidney. PAX3 (Paired Box 3) is a DNA-binding protein expressed during early neurogenesis. Two alternatively spliced isoforms are known as PAX3A and PAX3B. PAX3A and PAX3B transcription factors contain 215 and 206 amino acids, respectively. PAX3A was expressed only in cerebellum, esophagus, and skeletal muscle.

\section{Chromosome Region 7q}

Chromosome $7 \mathrm{q}$ is the region most frequently implicated in genome-wide studies (IMGSAC 1998, 2001a, 2001b; Ashley-Koch et al. 1999; Badner and Gershom 2002; Beyer et al. 2001; Liu et al. 2001; Alarcon et al. 2002; Auranen et al. 2002; Bonora et al. 2002; Molloy et al. 2005). The area implicated is broad, with two distinct peaks, 7q21-22 and 7q32-36. Limited evidence supports a role for paternal imprinting in this region (Ashley-Koch et al. 1999).

Linkage to chromosome $7 q$ was first identified by the International Molecular Genetic Study of Autism Consortium (IMGSAC) in 99 families in 1998 (IMGSAC 1998). These same regions have since been identified in independent samples, but attempts to refine these areas of linkage have not been successful. In support of the linkage findings, a meta-analysis by Badner and Gershon (2002) of the data from the IMGSAC (1998), the Stanford group (Risch et al. 1999), the PARIS (Paris Autism Research International Sibpair Study) group (Philippe et al. 1999) and the CLSA (Collaborative Linkage Study of Autism) showed significant linkage to this region. Another metaanalysis, by Trikalinos et al. (2006), also found genome-wide significant linkage to chromosome 7q22-32.

Chromosome $7 \mathrm{q}$ remains an area of intense interest for a number of reasons: First, as noted, multiple suggestive linkage signals have been reported in this interval and, while they are dispersed across a large area. A second source of interest has been the identification of a number of chromosomal rearrangements involving this interval in patients with autism. Finally, numerous brain-expressed transcripts map to the long arm of chromosome 7 and have known functions that could plausibly be involved in the pathophysiology of autism.

Five candidate genes, RELN, MET, EN2, NRCAM, and FOXP2 are reported by several investigators in this region and they have also 
tested association in these five candidate genes. In these five genes the most compelling candidate gene is FOXP2 (Forkhead Box P2) at $7 q 31$, and is disrupted in an autosomal dominant form of specific language impairment (SLI). Although initial studies did not implicate the coding region of FOXP2 in autism, further study is warranted after association to potential gene regulatory regions was reported in a larger sample of patients with SLI (O'Brien et al. 2003). FOXP2 gene regulates expression of the CNTNAP2 gene, which encodes a neurexin expressed in developing human cortex, by binding to a regulatory sequence in intron 1. Both FOXP2 and CNTNAP2 are involved in developmental speech and language disorders (Ramsay 2000; Newbury and Monaco 2002; Fisher et al. 2003; Bonneau et al. 2004; MacDermot et al. 2005). Several researchers reported association between FOXP2 and CNTNAP2 genes and autism (Li et al. 2005).

MET (MET proto oncogene) gene lies at $7 \mathrm{q} 31$, is also a strong functional candidate for involvement in autism because it encodes a receptor tyrosine kinase involved in neuronal growth and organization, as well as immunological and gastrointestinal functioning; these are systems in which abnormalities have been suggested in autism. Met gene lies at 7q31. Variants in the MET promoter region show strong association with autism. In particular, Campbell et al (2006) found significant over transmission of the common $\mathrm{C}$ allele in autism cases in multiple samples. Case-control comparisons found significant over-representation of the $\mathrm{C}$ allele in autism, with a relative risk of 2.27 folds. In a separate study, significantly decreased MET protein levels were found in autopsied cortical tissue from individuals with autism. The $\mathrm{C}$ risk allele is believed to be a functional regulator of the MET gene. Campbell et al. (2006) also found that mouse cells transfected with human MET promoter variants showed a 2-fold decrease in MET promoter activity associated with the $\mathrm{C}$ allele.

A third candidate gene, RELN (Reelin) on $7 q 22$, was originally identified in the mutant reeler mouse line and subsequently found in human autosomal recessive lissencephaly, a disorder of failed neuronal migration. The reelin (RELN) gene, which localizes to a site of chromosomal translocation at 7q22, encodes a large secreted glycoprotein that controls intracellular interactions (Rice et al. 2001). It is of particular interest given that it binds to neuronal receptors and that the pathology of autism can include migration cell defects (Bailey et al. 1998). Alterations in RELN protein affect cortical and cerebellar development, and the cerebellar neuronal abnormalities are among the more robust pathologic findings in autism (Kemper and Bauman 2002). Both family-based and population based association studies also indicate that variations in RELN may confer risk to autism. RELN maps to the $7 q 22$ chromosomal region, where suggestive or significant linkage to autism has been reported in several studies. Both family- and populationbased association studies also indicate that variations in RELN may confer risk to autism. In particular, a large polymorphic trinucleotide repeat in the 52 UTR of the RELN gene has been implicated in autism in several studies (Zhang et al. 2002). Preferential transmission of the large repeat polymorphisms to autistic versus unaffected siblings has also been reported (Persico et al. 2001; Li et al. 2004). A contribution of RELN in autism is further supported by studies of mutant reeler mice, which carry a large deletion in RELN and show atypical cortical organization similar to the cerebral abnormalities documented in postmortem studies in autism (Bailey et al. 1998).

EN2 (Engrailed 2) is located at 7q36.1 and is a homeobox gene that regulates development of the cerebellum. It has attracted attention as a result of the fact that cerebellum abnormalities are among the most consistent findings from pathological and neuroimaging studies in autism. Evidence for EN2 involvement in autism comes from a number of recent investigations (Gharani et al. 2004; Wang et al. 2008; Yang et al. 2008).

The fifth gene is NRCAM (Neuronal Cell Adhesion Molecule), which lies at 7q31.1. The cell adhesion molecules (CAMs) are a subset of the immunoglobin (Ig) superfamily found in the nervous systems. They are usually surface membrane proteins with multiple Ig domains at their $\mathrm{N}$ termini followed by several fibronectin type III repeats and either a transmembrane intracellular domain or a glycophosphatidylinositol-linked membrane anchor at the $\mathrm{C}$ terminus. NRCAM expression occurs highest levels in brain, adrenal medulla, and adrenal cortex and at intermediate levels in placenta, pancreas, thyroid, and testis.

\section{Chromosome Region 15q11q13}

Extensive genetic screens conducted by several groups have nearly confirmed the 
involvement of region 15q11-13 in autism (Sutcliffe et al. 2003; McCauley et al. 2004; Curran et al. 2005; Nurmi et al. 2005; Ashley-Koch et al. 2006). This region known for its instability is highly susceptible to clinically relevant genomic rearrangements, such as supernumerary marker chromosomes formed by the inverted duplication of proximal chromosome 15 . Inv dup (15) results in tetrasomy $15 \mathrm{p}$ and partial tetrasomy $15 \mathrm{q}$. Region 15q11-13 contains $\gamma$-amino butyric acid (GABA) receptor gene cluster for three of the receptor's subunits GABRB3, GABRA5, GABRG3, and UBE3A. GABA is the major inhibitory neurotransmitter in the mammalian CNS. The $\gamma$-amino butyric acid (GABAA) receptor gene is strongly implicated in the pathogenesis of autism, given its involvement in the inhibition of excitatory neural pathways and its expression in early development (Owens and Kriegstein 2003). Any malfunction of these genes may have implications for the inhibition of excitory neural pathways as well as during early brain development and therefore pathological for autism. Hussman (2001) suggested that autism is the result of an imbalance of the excitatory glutamatergic and inhibitory GABAergic pathways, resulting in over stimulation in the brain and inability to filter out excess stimuli from environmental and intrinsic sources. A couple of linkage and association studies reported limited evidence for involvement of the GABA receptors, where the most common positive linkage finding was within the GABRB3 gene (Martin et al. 2000; Buxbaum et al. 2002; McCauley et al. 2004; Curran et al. 2005; Ma et al. 2005; Ashley-Koch et al. 2006).

\section{Chromosome 17q}

Several linkage and genome wide screen reports supports the invlovment of 17q21region in autism (Cantor et al. 2005; McCauley et al. 2005). This region harbours Solute Carrier Family 6 (SLC6A4) gene (Serotonin transporter gene) at 17q11-q12 and encodes serotonin transporter. This may be a candidate gene because of hyperserotonemia observed in approximately $25 \%$ of patients with autism (Klauck et al. 1997; Yirmiya et al. 2001; Betancur et al. 2002). Serotonin (5hydroxytryptamine; (5-HT) is a neurotransmitter in the brain responsible for a couple of cognitive functions. Following release, serotonin is actively cleared from synaptic spaces by serotonin transporter (SLC6A4) which is a high-affinity, $\mathrm{Na}(+)$ - and $\mathrm{Cl}(-)$-dependent transporter localized in presynaptic neuronal membranes. Interest in this gene and its protein products derives from a plausible role for serotonin in the repetitive behaviors observed frequently in patients. Impaired function of serotonin system may result in depression, epilepsy, obsessive-compulsive behaviors and affective disorders. Klauck et al. (1997), attempting replication, reported preferential transmission of the larger allele, and the IMGSAC reported no association with either allele.

\section{Chromosome Xq}

$\mathrm{Xq}$ region harbours two genes, which may be candidate for autism- NLGN (neuroligin) and MeCP2 (Methyl-CpG-binding protein 2). Neuroligins are cell-adhesion molecules localised postsynatptically in both glutamatergic and gamma-aminobutyric acid-ergic (NLGN2) synapses (Muhle et al. 2004; Craig and Kang 2007), with important function in synaptogenesis during brain development and in connection of pre- and post-synaptic memebranes. Neuroligin 3 gene is located at Xp 22.3 and neuroligin 4 genes at atXq13. Extensive genetic screens conducted by several groups have confirmed the low frequency of neuroligin mutations among patients with autism (Jamain et al. 2003; Chih et al. 2004; Laumonnier et al. 2004; Yan et al. 2005; Lawson-Yuen et al. 2008). Lawson-Yuen et al. (2008) reported exonic deletion in NLGN4 in a family affected with autism, and a range of other learning and psychiatric disorders. A frameshift mutation in NLGN4 and a missense mutation in NLGN3 in two separate families have been found (Jamain et al. 2003) leading to functional inactivation of neuroligins (Chih et al. 2004). Laumonnier et al. (2004) found a frameshift mutation (D429X in NLGN4) in 13 affected male members of a single pedigree. Yan et al. (2005) reported four other NLGN4 missense mutations in patients with autism (G99S, K378R, V403M and R704C).

MeCP2 gene is located on chromosome $\mathrm{Xq} 28$, and binds to methylated $\mathrm{CpG}$ sites and associates with chromatin modifying factors histone deacetylase and DNA methyltransferase. This is a transcriptional repressor that binds to methylated $\mathrm{CpG}$ dinucleotides generally located at gene promoters and recruits HDAC1 and other 
Table 1: Notable putative chromosome bands studied for autism gene using linkage association strategies.

\begin{tabular}{|c|c|}
\hline Chromosomal Band & Reference \\
\hline $1 \mathrm{p} 13.2$ & Auranen et al.2002; Gupta and State 2006 \\
\hline $1 \mathrm{p} 21.2$ & Schellenberg et al.2006 \\
\hline $1 \mathrm{p} 22$ & Ylisaukko-oja et al. 2004; Gupta and State 2006 \\
\hline $1 \mathrm{p} 23.3$ & Ylisaukko-oja et al. 2004; Gupta and State 2006 \\
\hline $1 \mathrm{p} 36.23-\mathrm{p} 36.13$ & Alarcon et al. 2005 \\
\hline $1 \mathrm{q} 24.2$ & Buxbaum et al. 2004 \\
\hline $1 \mathrm{q} 42.2$ & Buxbaum et al. 2004 \\
\hline $2 \mathrm{q} 31.1$ & Buxbaum et al. 2001; IMGSAC 2001 \\
\hline $2 \mathrm{q} 32.1$ & Buxbaum et al. 2001 \\
\hline $2 q 33.1$ & Shao et al. 2002 \\
\hline $2 \mathrm{q} 37$ & Veenestra VanDerWeels and Cook 2003 \\
\hline $3 \mathrm{p} 24.1$ & Ylisaukko-oja et al.2004 \\
\hline $3 \mathrm{p} 25.3$ & McCauley et al. 2005; Gupta and State 2006 \\
\hline $3 q 13.31-q 26.1$ & Alarcon et al. 2005 \\
\hline $3 q 26.32$ & Auranen et al. 2002 \\
\hline $4 \mathrm{q} 23$ & Buxbaum et al. 2004 \\
\hline $4 \mathrm{q} 27$ & Buxbaum et al. 2004; Gupta and State 2006 \\
\hline $4 q 32.3$ & Ylisaukko-oja et al. 2004; Gupta and State 2006 \\
\hline $4 \mathrm{q} 34.1$ & Duvall et al. 2007 \\
\hline $5 \mathrm{p} 13.1$ & Yonan et al. 2003 ; Liu et al. 2001 \\
\hline $5 \mathrm{p} 15.2-\mathrm{p} 13.1$ & Alarcon et al. 2005 \\
\hline $5 q 12.3$ & Schellenberg et al. 2006 \\
\hline $5 q 21.3-q 23.1$ & Alarcon et al. 2005 \\
\hline $6 q 14.3$ & Buxbaum et al. 2004; Gupta and State 2006 \\
\hline $6 q 16.3$ & Philippe et al. 1999; Gupta and State 2006 \\
\hline $6 \mathrm{q} 25.3$ & Schellenberg et al.2006 \\
\hline $7 \mathrm{q} 31.1$ & Liu et al. 2001 \\
\hline $7 \mathrm{q} 34$ & Shao et al. 2002 \\
\hline $7 \mathrm{q} 35$ & Alarcon et al. 2002 \\
\hline $7 \mathrm{q} 36.1$ & Liu et al. 2001; Molloy et al. 2005 \\
\hline $9 \mathrm{p} 22.2$ & IMGSAC 2001; Gupta and State 2006 \\
\hline $9 \mathrm{q} 34.2$ & Schellenberg et al. 2006 \\
\hline $10 \mathrm{q} 11.23$ & Duvall et al. 2007 \\
\hline $10 \mathrm{q} 22.1-\mathrm{q} 23.22$ & Alarcon et al. 2005 \\
\hline 10p14-p15.3 & Alarcon et al. 2005 \\
\hline $11 \mathrm{p} 11.2-13$ & Yonan et al. 2003 \\
\hline $11 \mathrm{p} 15.4-\mathrm{q} 22.1$ & Duvall et al. 2007 \\
\hline $11 \mathrm{q} 23.3-\mathrm{q} 24.1$ & Alarcon et al. 2002,2005 \\
\hline $11 \mathrm{q} 25$ & Schellenberg et al. 2006 \\
\hline $13 q 12.3$ & Gupta and State 2006 \\
\hline $13 q 31-32.3$ & Ylisaukko-oja et al. 2004 \\
\hline $14 \mathrm{q} 32.2$ & Schellenberg et al. 2006 \\
\hline $15 \mathrm{q} 11-\mathrm{q} 13$ & Shao et al. 2003; Nurmi et al. 2003; Ma et al. 2005; Vorstman et al. 2005 \\
\hline $15 \mathrm{q} 21.2$ & IMGSAC 2001 \\
\hline $16 \mathrm{q} 24.1$ & Alarcon et al. 2005 \\
\hline $17 \mathrm{q} 11.2$ & Buzbaum et al. 2004; McCauley et al.2005 \\
\hline $17 \mathrm{p} 13.3$ & Duvall et al. 2007 \\
\hline $17 \mathrm{q} 21.32$ & Cantor et al. 2005 \\
\hline $17 q 23.2-q 25.1$ & Alarcon et al. 2005 \\
\hline $17 \mathrm{q} 24.3$ & Alarcon et al. 2005 \\
\hline $18 \mathrm{q} 23$ & Schellenberg et al. 2006 \\
\hline $19 \mathrm{p} 13$ & Liu et al.2001; McCauley et al.2004 \\
\hline $19 \mathrm{p} 13.12$ & Buxbaum et al. 2004;Gupta and State 2006 \\
\hline 20 p11.22-q13.32 & Alarcon et al. 2002, 2005 \\
\hline $21 \mathrm{q} 21.1$ & Molloy et al. 2005 \\
\hline $22 \mathrm{q} 13.1$ & Veenestra VanDerWeels and Cook 2003; Schellenberg et al.2006 \\
\hline $\mathrm{Xq} 21.33$ & Shao et al. 2002a;Gupta and State 2006 \\
\hline $\mathrm{Xq} 25$ & Liu et al. 2001; Gupta and State 2006 \\
\hline $\mathrm{Xq} 28$ & Gupta and State 2006 \\
\hline
\end{tabular}


proteins involved in chromatin repression. Several groups have screened the MECP2 gene for mutations in patients with autism (Vourc'h et al. 2001; Zappella et al. 2003; Shibayama et al. 2004; Li et al. 2005; Coutinho et al. 2007; Xi et al. 2007; Young et al. 2008) and reported framshift, nonsense, missense mutations and de novo splice variant in intron 2 (IVS2 + 2del TAAG). Importantly, female patients with autism carrying MECP2 mutations appear mentally retarded, but do not display any clinical trait resembling Rett syndrome.

\section{CONCLUSION AND RECOMMENDATIONS}

More than 30 years have passed since Folstein and Rutter (1977) first reported compelling evidence for a genetic etiology to autism in their landmark twin study and despite much progress the final definition of susceptibility genes underlying autism is still a challenge for the future. Data on multiple fronts lead to the conclusion that chromosome regions $2 \mathrm{q}, 7 \mathrm{q} 21,15 \mathrm{q} 11-\mathrm{q} 13$, $17 \mathrm{p}, \mathrm{Xq} 36$ contains one or more gene variants that cause autisms susceptibility. In summary, the identification of susceptibility genes in autistic disorder will depend on an interdisciplinary approach involving interaction between many groups using a combination of diagnostic, neurological, cytogenetic, affected sib pairs and candidate gene approach, micro array analysis for gene expression pattern in normal and autistic individuals and studies of animal models. The ultimate goal of autism genetic research is to define a series of genetic variants to be responsible for a specific symptomatology within the whole spectrum of disabilities in autism. Despite all the difficulties regarding candidate genes identification for autism, there are still several hopes to believe that once the gene involved are known, new therapeutic agents may be identified in future to act on target molecular. The two main worst facts about autism are first the causes and presentation of autism are confusing and complicate the diagnosis and the second one is its continuously increasing prevalence rate. Researchers have reported that the early diagnosis and intervention significantly improve an autistic child's long-term outcome (Muhle 2004). Therefore, Psychiatrist/Pediatrics' should identify autism expeditiously at an early age and also should educate families regarding recurrence risk, and also the causes of autism. With the understanding of the genetic causes of autism, prenatal screening and counseling should become available for affected families and may certainly help to reduce the incidence rates of autism.

\section{REFERENCES}

Alarcon M, Cantor RM, Liu J, Gilliam TC, Geschwind DH 2002.Evidence for a language quantitative trait locus on chromosome $7 \mathrm{q}$ in multiplex autism families. Am J Hum Genet, 70: 60-71.

Alarcon M, Yonan AL, Gilliam TC, Cantor RM, Geschwind DH 2005. Quantitative genome scan and ordered-subsets analysis of autism endophenotypes support language QTLs. Mol Psychiatry, 10: 747757.

American Psychiatric Association (APA) 1994. Diagnostic and Statistical Manual of Mental Disorders. Washington, DC: American Psychiatric Association.

Ashley-Koch A, Wolpert CM, Menold MM, Zaeem L, Basu $S$ et al. 1999. Genetic studies of autistic disorder and chromosome 7. Genomics, 61: 227236.

Ashley-Koch AE, Me H, Gasworks J, Ma DQ, Ritchie MD et al. 2006. An analysis paradigm for investigating multi-locus effects in complex disease: Examination of three GABA receptor subunit genes on $15 \mathrm{q} 11-\mathrm{q} 13$ as risk factors for autistic disorder. Ann Hum Genet, 70: 281-292.

Asperger H 1944. Die autistischen psychopathen im kindesalter. Arch Psychiatr Nervenkr, 117: 76-136.

Auranen M, Vanhala R, Varilo T, Ayers K, Kempas E et al. 2002. A genome-wide screen for autism-spectrum disorders: Evidence for a major susceptibility locus on chromosome 3q25-27. Am J Hum Genet, 71: 777-790.

Badner JA, Gershon ES 2002. Regional meta-analysis of published data supports linkage of autism with markers on chromosome 7. Mol Psychiatry, 7: 5666.

Baker P, Piven J, Sato Y 1998. Autism and tuberous sclerosis complex:prevalence and clinical features. J Autism Dev Disord, 28:279-285.

Baieli S, Pavone L, Meli C, Fiumara A, Coleman M 2003. Autism and phenylketonuria. J Autism Dev Disord, 33: 201-204.

Bailey A, Phillips W, Rutter M 1996. Autism: Towards and integration of clinical, genetic, neuropsychological, and neurobiological perspectives. J Child Psychol Psychiatr, 37(1): 89-126.

Bailey A, Palferman S, Heavey L, Le Couteur A 1998. Autism: the phenotype in relatives. J Autism Dev Disord, 28: 369-392

Barrett S, Beck JC, Bernier R, Bisson E, Braun TA, Casavant TL et al. 1999. An autosomal genomic screen for autism. Collaborative linkage study of autism. Am Med Genet, 88: 609-615.

Bauman ML, Kemper TL 2005. Neuroanatomic observations of the brain in autism: a review and future directions. Int J Dev Neurosci, 23: 183-187.

Betancur C, Corbex M, Spielewoy C, Phillipe A, 
Laplanche J-L et al. 2002. Serotonin transporter gene polymorphisms and hyperserotonemia in autistic disorder. Mol Psychiatry, 7: 67-71.

Beyer KS, Klauck SM, Wiemann S, Poustka A 2001. Construction of a physical map of an autism susceptibility region in 7q32.3-q33. Gene, 272: 8591.

Bonneau D, Verny C, Uzé J 2004.Genetics of specific language impairments. Arch Pediatr, 11(10): 12131236 .

Bonora E, Bacchelli E, Levy ER, Blasi F, Marlow A et al. 2002. Mutation screening and imprinting analysis of four candidate genes for autism in the 7q32 region. Mol Psychiatry, 7: 289-301.

Buxbaum JD, Silverman JM, Smith CJ, Kilifarski M, Reichert J et al. 2001. Evidence for a susceptibility gene for autism on chromosome 2 and for genetic heterogeneity. Am J Hum Genet, 68: 1514-1520.

Buxbaum JD, Silverman JM, Smith CJ, Greenberg DA, Kilifarski $\mathrm{M}$ et al. 2002. Association between a GABRB3 polymorphism and autism. Mol Psychiatry, 7: 311-316.

Buxbaum JD, Silverman J, Keddache M, Smith CJ, Hollander E et al. 2004. Linkage analysis for autism in a subset families with obsessive-compulsive behaviors: Evidence for an autism susceptibility gene on chromosome 1 and further support for susceptibility genes on chromosome 6 and 19. Mol Psychiatry, 9: 144-150.

Campbell DB, Sutcliffe JS, Ebert PJ, Militerni R, Brvaccio $\mathrm{C}$ et al 2006. A genetic variant that disrupts MET transcription is associated with autism. Proc Natl Acad Sci USA, 103:16834-168339.

Cantor R.M, Kono N, Duvall JA, Alvarez-Retuerto A, Stone JL et al. 2005. Replication of autism linkage: fine-mapping peak at 17q21. Am J Hum Genet, 76: $1050-1056$.

Chen CH, Hsiao KJ 1989. A Chinese classic phenyIketonuria manifested as autism. Br J Psychiatry, 155: 251-253

Chih B, Afridi SK, Clark L, Scheiffele P 2004. Disorderassociated mutations lead to functional inactivation of neuroligins. Hum Mol Genet, 13: 1471- 1477.

Christian SL, Brune CW, Sudi J, Kumar RA, Liu S et al. 2008. Novel submicroscopic chromosomal abnormalities detected in autism spectrum disorder. Biol Psychiatry, 63: 1111-1117.

Coutinho AM, Oliveira G, Katz C, et al 2007 MECP.2 coding sequence and 39UTR variation in 172 unrelated autistic patients. Am J Med Genet B Neuropsychiatr Genet, 144B: 475-83.

Craig AM, Kang Y 2007. Neurexin-neuroligin signaling in synapse development. Curr Opin Neurobiol, 17: $43-52$.

Curran S, Roberts S, Thomas S, Veltman M, Browne J et al. 2005. An association analysis of microsatellite markers across the Prader-Willi/Angelman critical region on chromosome 15 (q11-13) and autism spectrum disorder. Am J Med Genet B Neuropsychiatr Genet, 137: 25-28.

Descheemaeker MJ, Govers V, Vermeulen P, Fryns JP 2006. Pervasive developmental disorders in PraderWilli syndrome: The Leuven experience in 59 subjects and controls. Am J Med Genet A, 140:1136-1142.

Duvall JA, Lu A, Cantor RM, Todd RD, Constantino JN,
Geschwind DH 2007. A quantitative trait locus analysis of social responsiveness in multiplex autism families. Am J Psychiatry, 164: 656-662.

Eisenstat DD, Liu JK, Mione M, Zhong W, Yu G et al. 1999. DLX-1, DLX-2 and DLX-5 expression define distinct stages of basal forebrain differentiation. $J$ Comp Neurol, 414: 217-237.

Feng J, Schoer R, Yan J 2006. High frequency of neurexin 1 beta signal peptide structural variants in patients with autism. Neurosci Lett, 409: 10-13.

Fisher SE, Lai CS, Monaco AP 2003. Deciphering the genetic basis of speech and language disorders. Аппи Rev Neurosci, 26: 57-80.

Folstein S, Rutter M 1977. Infantile autism: A genetic study of 21 twin pairs. J Child Psychol Psychiatry, 18: $297-321$.

Fombonne E 2002. Epidemiological trends in rates of autism. Mol Psychiatry, 7: S4-S6.

Gharani N, Benayed R, Mancuso V, Brzustowicz LM, Millonig JH 2004. Association of the homeobox transcription factor, ENGRAILED 2, 3, with autism spectrum disorder. Mol Psychiatry, 9(5): 474-84.

Gillberg C, Steffenburg S 1989. Autistic behaviour in Moebius syndrome. Acta Paediatr Scand, 78:314316

Gupta AR, State M 2006. Autism genetics. Rev Bras Psiquiatr, 28: 529-38.

Hussman JP 2001. Suppressed GABAergic inhibition as a common factor in suspected etiologies of autism. J Autism Dev Disord, 31: 247-248.

International Molecular Genetic Study of Autism Consortium (IMGSAC) 1998. A full genome screen for autism with evidence for linkage to a region on chromosome 7q. Hum Mol Genet, 7: 571-578.

International Molecular Genetic Study of Autism Consortium (IMGSAC) 2001a. A genome-wide screen for autism: strong evidence for linkage to chromosomes 2q, 7q, and 16p. Am J Hum Genet, 69: 570-581.

International Molecular Genetic Study of Autism Consortium (IMGSAC) 2001b. Further characterization of the autism susceptibility locus AUTS1 on chromosome 7q. Hum Mol Genet, 10: 973-982.

Jamain S, Quach H, Betancur C, Rastam M, Colineaux C et al. 2003. Mutations of the X-linked genes encoding neuroligins NLGN3 and NLGN4 are associated with autism. Nat Genet, 34: 27-29.

Kanner, L 1943. Autistic disturbances of affective contact. Nervous Child, 2: 217-250.

Kemper TL, Bauman ML 2002.Neuropathology of infantile autism. Mol Psychiatry, 7: S12-S13.

Kim HG, Kishikawa S, Higgins AW 2008. Disruption of neurexin 1 associated with autism spectrum disorder. Am J Hum Genet, 82: 199-207.

Klauck SM, Poustka F, Benner A, Lesch KP, Poustka A 1997. Serotonin transporter (5-HTT) gene variants associated with autism? Hum Mol Genet, 6: 22332238 .

Komoto J, Usui S, Otsuki S, Terao A 1984. Infantile autism and Duchenne muscular dystrophy. J Autism Dev Disord, 14: 191-195.

Lamb JA, Barnby G, Bonora E, Sykes N, Bacchelli E et al. 2005. Analysis of IMGSAC autism susceptibility loci: evidence for sex limited and parent of origin specific effects. J Med Genet, 42: 132-137. 
Laumonnier F, Bonnet-Brilhault F, Gomot M, Blanc R, David A et al. 2004. X-linked mental retardation and autism are associated with a mutation in the NLGN4 gene, a member of the neuroligin family. Am J Hum Genet, 74: 552-557.

Lawson-Yuen A, Saldivar JS, Sommer S, Picker J 2008. Familial deletion within NLGN4 associated with autism and Tourette syndrome. Eur J Hum Genet, 16: 614-618.

Li J, Nguyen L, Gleason C, Lotspeich L, Spiker D et al. 2004. Lack of evidence for an association between WNT2 and RELN polymorphisms and autism. Am J Med Genet, 126: 51-57.

Li JY, Kuick R, Thompson RC, Misek DE, Lai YM et al. 2005. Arcuate nucleus transcriptome profiling identifies ankyrin repeat and suppressor of cytokine signalling box-containing protein 4 as a gene regulated by fasting in central nervous system feeding circuits. J Neuroendocrinol, 17: 394-404.

Liu J, Nyholt DR, Magnussen P, Parano E, Pavone P et al. 2001. A genome-wide screen for autism susceptibility loci. Am J Hum Genet, 69: 327-340.

Ma DQ, Whitehead PL, Menold MM, Martin ER, AshleyKoch AE et al. 2005. Identification of significant association and gene-gene interaction of GABA receptor subunit genes in autism. Am J Hum Genet, 77: $377-388$.

MacDermot KD, Bonora E, Sykes N et al. 2005. Identification of FOXP2 truncation as a novel cause of developmental speech and language deficits. Am J Hum Genet, 76(6): 1074-1080.

Marshall CR, Noor A, Vincent JB et al 2008. Structural variation of chromosomes in autism spectrum disorder. Am J Hum Genet, 82: 477-488.

Martin ER, Menold MM, Wolpert CM, Bass MP, Donnelly SL et al. 2000. Analysis of linkage disequilibrium in gamma-aminobutyric acid receptor subunit genes in autistic disorder. Am J Med Genet, 96: 43-48.

McCauley JL, Olson LM, Delahanty R, Delahanty R, Amin $\mathrm{T}$ et al. 2004. A linkage disequilibrium map of the $1-\mathrm{Mb} 15 \mathrm{q} 12 \mathrm{GABA}(\mathrm{A})$ receptor subunit cluster and association to autism. Am J Med Genet B Neuropsychiatr Genet, 131: 51-59.

McCauley JL, Li, C, Jiang L, Olson LM, Crockett G et al. 2005. Genome-wide and ordered-subset linkage analyses provide support for autism loci on $17 \mathrm{q}$ and $19 \mathrm{p}$ with evidence of phenotypic and interlocus genetic correlates. BMC Med Genet, 6: 1.

Miladi N, Larnaout A, Kaabachi N, Helayem M, Ben Hamida M 1992. Phenylketonuria: An underlying etiology of autistic syndrome. A case report. $J$ Child Neurol, 7: 22-23.

Molloy CA, Keddache M, Martin LJ 2005. Evidence for linkage on $21 \mathrm{q}$ and $7 \mathrm{q}$ in a subset of autism characterized by developmental regression. Mol Psychiatry, 10: 741- 746.

Morrow JD, Whitman BY, Accardo PJ 1990. Autistic disorder in Sotos syndrome: A case report. Eur $J$ Pediatr, 149: 567-569.

Muhle R, Trentacoste SV, Rapin I 2004. The genetics of autism. Pediatrics, 113: 472-486.

Newbury DF, Monaco AP 2002. Molecular genetics of speech and language disorders. Curr Opin Pediatr, 14(6): 696-701.
Nurmi EL, Amin T, Olson LM, Jacobs MM, McCauley J et al. 2003. Dense linkage disequilibrium mapping in the 15q11-q13 maternal expression domain yields evidence for association in autism. Mol. Psychiatry, 8: 624-634, 570.

O'Brien EK, Zhang X, Nishimura C, Tomblin JB, Murray JC 2003. Association of specific language impairment (SLI) to the region of $7 \mathrm{q} 31$. Am J Hum Genet, 72: 1536-1543.

Owens DF, Kriegstein AR 2002. Is there more to GABA than synaptic inhibition? Nat Rev Neurosci, 3: 715727.

Ozonoff S, Williams BJ, Gale S, Miller JN 1999.Autism and autistic behaviour in Jobert Syndrome. J Child Neurol, 14: 636-641.

Persico AM, D’Agruma L, Maiorano N, Totaro A, Militerni R et al. 2001. Reelin gene alleles and haplotypes as a factor predisposing to autistic disorder. Mol Psychiatry, 6: 150-159.

Philippe A, Martinez M, Guilloud-Bataill M, Gillberg C, Rastam M et al. 1999. Genome-wide scan for autism susceptibility genes. Paris Autism Research International Sibpair Study. Hum Mol Genet, 8: 805812 .

Ramsay M 2000. Communication genes clustered on 7q31. Mol Med Today, 6(10): 380-381.

Rapin I, Katzman R 1998. Neurobiology of autism. Ann Neurol, 43: 7-14.

Rasmussen P, Borjesson O, Wentz E, Gillberg C 2001. Autistic disorders in Down syndrome: background factors and clinical correlates. Dev Med Child Neurol, 43: 750-754.

Reddy KS 2005. Cytogenetic abnormalities and fragile $\mathrm{X}$ syndrome in Autism spectrum disorder. $B M C$ Medical Genetics, 6: 3.

Rice DS, Nusinowitz S, Azimi AM, Martinez A, Soriano E, Curran T 2001. The reelin pathways modulates the structure and function of retinal synaptic circuitry. Neuron, 31: 929-941.

Reiss AL, Feinstein C, Rosenbaum KN, BorengasserCaruso MA, Goldsmith BM. 1985. Autism associated with Williams syndrome. J Pediatr, 106: 247-249.

Risch N, Spiker D, Lotspeich L, Nassim N, Hinds D et al. 1999. Genomic screen of autism: evidence for a multilocus etiology. Am J Hum Genet, 65: 493-507.

Rogers SJ, Wehner DE, Hagerman R 2001. The behavioral phenotype in fragile X: symptoms of autism in very young children with fragile $\mathrm{X}$ syndrome, idiopathic autism, and other developmental disorders. $J$ Dev Behav Pediatr, 22: 409-417.

Schellenberg GD, Dawson G, Sung YJ 2006. Evidence for multiple loci from a genome scan of autism kindreds. Mol Psychiatry, 11: 1049-60.

Shao, Y, Wolpert C.M, Raiford KL, Menold MM, Donnelly SL et al. 2002a. Genomic screen and follow-up analysis for autistic disorder. Am J Med Genet, 114: 99-105.

Shao Y, Raiford KL, Wolpert CM, Cope HA, Ravan SA et al. 2002b. Phenotypic homogeneity provides increased support for linkage on chromosome 2 in autistic disorder. Am J Hum Genet, 70: 1058-1061.

Shao Y, Cuccaro ML, Hauser ER, Raiford KL, Menold MM et al. 2003. Fine mapping of autistic disorder to chromosome $15 \mathrm{q} 11-\mathrm{q} 13$ by use of phenotypic subtypes. Am J Hum Genet, 72: 539-548. 
Shibayama A, Cook EH Jr, Feng J 2004. MECP2 structural and 39-UTR variants in schizophrenia, autism and other psychiatric diseases: a possible association with autism. Am J Med Genet B Neuropsychiatr Genet, 128B: 50-53.

Steffenburg S, Gillberg CL, Steffenburg U, Kyllerman M 1996. Autism in Angelman syndrome: a populationbased study. Pediatr Neurol, 14: 131-136.

Sutcliffe JS, Nurmi EL, Lombroso PJ. 2003. Genetics of childhood disorders: XLVII. Autism, part 6: Duplication and inherited susceptibility of chromosome 15q11-q13 genes in autism. J Am Acad Child Adolesc Psychiatry, 42: 253-256.

Szatmari P, Paterson AD, Zwaigenbaum L 2007. Mapping autism risk loci using genetic linkage and chromosomal rearrangements. Nat Genet, 39: 319-328.

Trikalinos TA, Karvouni A, Zintzaras E, Ylisaukko-oja T, Peltonen L et al. 2006. A heterogeneity-based genome search meta-analysis for autism-spectrum disorders. Mol Psychiatry, 11: 29-36.

Veenstra-VanderWeels J, Cook Jr EH 2004. Molecular genetics of autism spectrum disorder. Mol Psychiatry, 9: 819-831.

Vorstman JA, Staal WG, van Daalen E, van Engeland H, Hochstenbach PF, Franke L 2006. Identification of novel autism candidate regions through analysis of reported cytogenetic abnormalities associated with autism. Mol Psychiatry, 11: 18-28.

Vourc'h P, Bienvenu T, Beldjord C, Chelly J, Barthelemy $\mathrm{C}$ et al. 2001. No mutations in the coding region of the Rett syndrome gene MeCP2 in 59 autistic patients. Eur J Hum Genet, 9: 556-558.

Waage-Baudet H, Lauder JM, Dehart DB 2003. Abnormal serotonergic development in a mouse model for the Smith-Lemli-Opitz syndrome: implications for autism. Int J Dev Neurosci, 21: 451-459.

Wang L, Jia M, Yue W 2008. Association of the ENGRAILED 2 (EN2) gene with autism in Chinese Han population. Am J Med Genet B Neuropsychiatr Genet, 147B(4): 434-438

Wassink T, Piven J, Vieland V,Huang J, Swiderski R et al. 2001. Evidence supporting WNT2 as an autism susceptibility gene. Am J Med Genet (Neuropsychiatr Genet), 105: 406-413.
Xi CY, Ma HW, Lu Y, Zhao YJ, Hua TY, Zhao Y, Ji YH 2007. MeCP2 gene mutation analysis in autistic boys with developmental regression. Psychiatr Genet, 17: 113-116.

Yan, J, Oliveira G, Coutinho A, Yang C, Fen, J et al. 2005. Analysis of the neuroligin 3 and 4 genes in autism and other neuropsychiatric patients. Mol Psychiatry, 10: 329-332.

Yan J, Noltner K, Feng J 2008. Neurexin 1alpha structural variants associated with autism. Neurosci Lett, 438: 368-370.

Yang P, Lung FW, Jong YJ, Hsieh HY, Liang CL, Juo SH 2008. Association of the homeobox transcription factor gene ENGRAILED 2 with autistic disorder in Chinese children. Neuropsychobiology, 57: 3-8.

Yeargin-Allsopp M, Rice C, Karapurkar T, Arbella S, Feinsilver T et al. 2003. Prevalence of autism in a US metropolitan area. JAMA, 289: 49-55.

Yirmiya N, Pilowsky T, Nemanov L, Arbella S, Feinsilver $\mathrm{T}$ et al. 2001. Evidence for an association with the serotonin transporter promoter region polymorphism and autism. Am J Med Genet, 105: 381-386.

Ylisaukko-oja T, Nieminen-von Wendt, Kempas E et al 2004. Genome-wide scan for loci of Asperger syndrome. Mol Psychiatry, 9: 161-168.

Yonan AL, Alarcon M, Cheng R, Magnusson PK, Spence SJ et al. 2003. A genome-wide screen of 345 families for autism-susceptibility loci. Am J Hum Genet, 73: 886-897.

Young DJ, Bebbington A, Anderson A, ravine D, Ellaway C et al. 2008. The diagnosis of autism in a female: could it be Rett syndrome? Eur J Pediatr, 167: 661669.

Yu CE, Dawson G, Munson J 2002. Presence of large deletions in kindreds with autism. Am J Hum Genet, 71: $100-115$.

Zappella M, Meloni I, Longo I, Canitano R, Hayek G et al.2003. Study of MECP2 gene in Rett syndrome variants and autistic girls. Am J Med Genet B Neuropsychiatr Genet, 119B: 102-7.

Zhang H, Liu X, Zhang C, Munod E, Macciardo F et al. 2002. Reelin gene alleles and susceptibility to autism spectrum disorders. Mol Psychiatry, 7: 1012- 1017. 